\title{
MODEL SISTEM INSTITUSI MADRASAH NIDZAMIYAH DI ERA DINASTI
}

\section{SALJUK}

\author{
Sukijan Athoillah 1) * \\ ${ }^{1}$ Universitas Islam Sultan Agung \\ *E-mail: sukijan@unissula.ac.id
}

\begin{abstract}
This research discusses a model of the Nidzamiyah madarasah institutional system during the reign of the Seljuq dynasty. The system model includes characteristics, mission, curriculum, remuneration system for teachers, students and teachers, and socio-political aspects. This research uses a descriptive qualitative approach. The type of research is library research. Data collection techniques in this study used the documentation method to review madrasah documents related to the learning process of child labor. The results of this study indicate that madrasas in the Saljuk Dynasty were the highest educational institutions. However, madrasas cannot be equated with universities, because madrasah have different characteristics. The characteristics of madrasah that differentiate them from universities can be seen from the curriculum, conditions of teachers and students, as well as socio-political nuances.
\end{abstract}

Keywords: Model, Madrasah Nidzamiyah, Seljuq Dynasty

\begin{abstract}
Abstrak
Penelitian ini membahas tentang sebuah model sistem institusi madarasah Nidzamiyah pada masa pemerintahan Dinasti Saljuk. Model sistem tersebut meliputi karkateristik, misi, kurikulum, sistem penggajian guru, murid dan guru, dan aspek sosial-politik. Penelitian ini menggunakan pendekatan kualitatif deskriptif. Adapun jenis penelitiannya adalah library research (studi kepustakaan). Teknik pengumpulan data dalam penelitian ini menggunakan metode dokumentasi untuk mengkaji dokumen madrasah terkait proses belajar pekerja anak. Hasil penelitian ini menunjukkan bahwa madrasah pada zaman Dinasti Saljuk merupakan lembaga pendidikan tertinggi. Namun madrasah tidak dapat disamakan dengan universitas, karena madrasah memiliki karakteristik yang berbeda. Karakteristik madrasah yang membedakan dengan universitas dapat dilihat dari kurikulum, kondisi guru dan murid, serta nuansa sosial-politik.
\end{abstract}

Kata Kunci: Model, Madrasah Nidzamiyah, Dinasti Saljuk

\section{PENDAHULUAN}

Sejarah berjalan dari masa lalu menuju ke masa kini dan melanjutkan ke masa yang akan datang. Dalam perjalanan suatu unit sejarah selalu mengalami pasang naik dan pasang surut dalam interval yang berbeda-beda. Menurut Nourouzzaman Shiddiqie dalam Syamsul Munir Amin, periodesasi sejarah peradaban Islam disusun menjadi tiga, yaitu periode klasik (600-1258 M), periode tengah (1258-1800 M), dan periode modern (1800-sekarang)(Amin, 2010: 15-17). Pada masa periode 
pertengahan ini lahir Dinasti Saljuk yang didirikan oleh Tughil Beg pada tahun $1037 \mathrm{M}$ (Suwito \& Fauzan, 2008: 147-148).

Berbicara tentang Dinasti Saljuk, maka tidak lepas dari nama Nidzam Al-Mulk. Nidzam Al-Mulk adalah wazir Dinasti Saljuk mulai tahun 456/1063 sampai dengan 485/1092(Asari, 1994: 48). Kepemimpinan Nidzam Al-Mulk merupakan bagian puncak keemasan peradaban Islam, terutama dalam bidang pendidikan. Karena pada pemerintahannya berdiri madarasah sebagai lembaga pendidikan setelah masjid dan masjid-khan. Perkembangan madrasah sebagai lembaga pendidikan Islam di awali dari perkembangan pendidikan yang dilakukan di masjid, yang kemudian berlanjut ke masjid-khan. Karena seiring dengan perkembangan zaman dan tidak semua bidang studi bisa diajarkan di masjid, maka berdirinya madrasah adalah sebagai jawaban dari keterbatasan fungsi masjid dan masjid-khan tersebut dalam dunia pendidikan (Rohman, 2017).

Madrasah Nidzamiyah bukanlah sebuah madrasah yang berada di satu tempat tertentu. Dalam perkembangannya Madrasah Nidzamiyah didirikan di berbagai negara. Madrasah yang pertama kali didirikan oleh Nidzam Al-Mulk di Nisyapur pada tahun 1050 M, kemudian menyusul madrasah di Baghdad pada tahun 1065-1067 M. Lalu di kota-kota lain yaitu di Basrah, isfahan, Herat, Baikh dan Mosul (Al-Furqon, Deprison, 2020).

Madrasah ini pula yang kemudian melahirkan Imam Al-Ghazali. Dia adalah seorang ulama besar dan kenamaan yang mempengaruhi jalan sejarah umat Islam yang sebelumnya menganut aliran syi'ah kemudian pada masa berikutnya terutama di dunia Islam belahan timur yang mayoritas beraliran sunni. Maka dari itu, cukup menarik untuk dikaji dan diteliti. Kemudian dihubungkan dengan sistem pendidikan di Madrasah Nidzamiyah yang bisa melahirkan ulama yang terkenal sepanjang masa. Hasil kajian ini dapat digunakan sebagai salah satu referensi atau refleksi untuk melakukan pembaharuan madrasah di Indonesia. Karena madrasah di Indonesia baru populer setelah awal abad keduapuluh (Daulay, 2009: 21).

Karena begitu luasnya pembahasan tentang sistem Madrasah Nidzamiyah, maka penulis membatasi pembahasan dalam lingkup arakteristik institusi pendidikan madrasah, misi, kurikulum, sistem penggajian guru, syarat murid dan guru, dan aspek sosial politik Madrasah Nidzamiyah. 


\section{METODE PENELITIAN}

Penelitian ini menggunakan pendekatan kualitatif deskriptif, yaitu menjelaskan secara kualitatif tentang sistem institusi Madrasah Nidzamiyah yang berjaya pada masa pemerintah Dinasti Saljuk. Jenis penelitian yang dipilih adalah penelitian kepustakaan (library research). Sehubungan penelitian ini merupakan penelitian kepustakaan, maka data diperoleh dari sumber tertulis. Mesikupun dikatakan bahwa sumber di luar kata dan tindakan merupakan sumber kedua, namun menurut Moleong, sumber tertulis tidak bisa diabaikan. Sumber tertulis bisa berupa sumber buku dan majalah ilmiah, sumber dari arsip, dokumentasi pribadi, dan dokumen resmi (Moleong, 2016: 159).

Sebagai upaya untuk meningkatkan objektifitas dan menjaga konsistensi, peneliti mengklasifikasikan sumber tertulis tersebut menjadi dua bagian. Pertama, data primer yang terdiri dari buku yang membahas langsung tentang sistem institusi Madrasah Nidzamiyah, seperti Menyingkap Zaman Keemasan Islam karya Hasan Asari. Kedua, data sekunder yang terdiri dari referensi tambahan yang tidak membahas langsung tema yang diteliti tetapi memiliki keterkaitan. Ketiga, data tersier yang terdiri dari referensi lain yang tidak dibutuhkan tetapi perlu digunakan untuk memperkuat penemuan, seperti internet.

Pengumpulan data dalam penelitian menggunakan metode dokumentasi. Karena penelitian ini adalah studi kepustakaan (library research), sehingga tidak memerlukan metode wawancara. Sebab, pelaku dalam sejarah sudah meninggal jauh sebelum bukubuku itu ditulis.

\section{MODEL SISTEM INSTITUSI MADRASAH NIDZAMIYAH}

\section{A. Karakteristik Institusi Pendidikan Madrasah}

Kata 'madrasah' dalam bahasa Indonesia merupakan serapan dari bahasa Arab, madrasah. Maka dari itu supaya lebih fokus, perlu dicacat bahwa madrasah (bahasa Arab) yang akan dibicarakan pada bagian ini tidak sama dengan madrasah (bahasa Indonesia), yang adalah lembaga pendidikan dasar atau menengah. Madrasah yang dimaksudkan adalah lembaga pendidikan tinggi yang berkembang di dunia Islam pra-modern, sebelum era universitas (Al-Jami'ah).

Hasan Fahmi sebagaimana yang dikutip oleh Samsul Nizar, menyatakan bahwa madrasah merupakan satu jenis lembaga pendidikan tinggi yang muncul 
pada akhir abad IV Hijriyah. Karakteristik madrasah sebagai lembaga pendidikan tertinggi pada masa awal berdirinya tidak dapat disamakan dengan secara persis dengan lembaga pendidikan tinggi yang ada sekarang. Para ahli sejarah menerjemahkan madrasah ke dalam berbagai bahasa, tetapi tidak satu pun dari hasil terjemahan itu yang dapat menggambarkan madarasah secara tepat (Nizar, 2011: 158). Jika kemunculan madarasah pada akhir abad ke IV Hijriyah, maka dapat dikatakan bahwa bahwa madrasah muncul dalam sejarah pendidikan masa pertengahan (1258-1800).

Menurut Makdisi (dalam Asari), setidaknya ada tiga perbedaan mendasar antara madrasah dan universitas; Pertama, kata universitas dalam pengertian yang paling awal merujuk pada komunitas atau sekelompok sarjana dan mahasiswa, sementara madrasah merujuk pada bangunan tempat kegiatan pendidikan tinggi berlangsung. Kedua, universitas bersifat hirarkis dengan konsekuensi sistem kontrol yang jelas, sedangkan madrasah bersifat individualistis dan personal dengan kontrol otoritas yang sangat lemah. Ketiga, izin mengajar pada universitas dikeluarkan oleh komite, sedangkan pada madrasah diberikan oleh syaikh secara personal tanpa terkait dengan pemerintah politik atau yang lainnya (Asari, 1994: 44-45). Dengan demikian, dapat kita ketahui bahwa madrasah memiliki karakteristik yang lebih mandiri dibanding dengan universitas.

\section{B. Misi Madrasah Nidzamiyah}

Misi dari Madrasah Nidzamiyah tidak tertulis secara jelas seperti misi madrasah saat ini, yang terkadang terpajang sebagai salah satu hiasan dinding. Nidzam Al-Mulk mendirikan Madrasah Nidzamiyah sebagai sebuah solusi atas permasalahan pada saat itu dan sebagai upaya pengembangan pendidikan Islam. Maka dari itu, misi Nidzham Al-Mulk tidak lepas dari permasalahan yang melatar belakangi berdirinya madrasah tersebut, diantaranya adalah sebagai berikut:

Pertama, pada abad ke-5/11 adalah masa di mana sejarah mencatat terjadinya konflik antara kelompok-kelompok keagamaan dalam Islam, misalnya Mu'tazilah, Syi'ah, Asy'ariyah, Hanafiyah, Hanbaliyah, dan syafi'iyah. Wazir Saljuk sebelum Nidzam Al-Mulk adalah al-Kunduri seorang bermadzhab Hanafi dan pendukung Mu'tazilah. (Para sultan saljuq sendiri adalah dari kelompok Hanafiyah). Salah kebijakannya sebagai wazir adalah mengusir dan menganiaya 
para penganut Asy-ariyah yang seringkali juga penganut madzhab Syafi'i. Pendapat para pengkaji terdahulu tentang misi Nidzam Al-Mulk untuk menghancurkan kelompok lain tidak didasarkan atas alasan dan bukti yang jelas. Maka oleh Asari, salah satu misi Nidzam Al-Mulk mendirikan madrasahnya adalah untuk memperbaiki keadaan kelompok Syafi'iyah sekaligus menciptakan stabilitas negara (Asari, 1994: 50-52).

Kedua, Dinasti Saljuk merupakan negara besar sehingga memiliki sistem administrasi yang sangat luas. Nidzam Al-Mulk harus memberikan perhatian yang besar terhadap sistem administrasi negara. Oleh sebab itu, dia memprioritaskan pembangunan satu administrasi sentral (Baghdad) yang kokoh dengan sistem kendali yang kuat dan berpengaruh. Maka Madrasah Nidzamiyah membantu sistem administrasi negara dengan upaya mengeluarkan lulusan-lulusan yang siap bekerja untuk pemerintahan Nidzam Al-Mulk, sebagai katib (sekretaris), qadhi (hakim), dan sebagainya (Asari, 1994: 53).

\section{Kurikulum Madrasah Nidzamiyah}

Secara sederhana, kurikulum dapat diartikan sebagai seperangkat mata pelajaran yang wajib ditempuh oleh siswa dalam jenjang pendidikan tertentu. Namun secara luas, kurikulum dapat dimaknai segala pengalaman yang diperoleh siswa, baik di dalam kelas maupun di luar kelas, selama masih di lingkungan sekolah. Kurikulum dalam artian luas ini mencakup unsur kemanusiaan (human) dan non-human. Unsur human mencakup kepala sekolah, pengawas, guru, murid, staf tata usaha, dan staf kebersihan. Sedangkan unsur non-human mencakup sarana dan prasarana, kondisi ruang kelas, dan lingkungan sekolah pada umumnya.

Dalam rangka memahami kurikulum secara lebih tepat dalam kontek pengembangan ilmu pengertahuan, maka perlu dibicarakan klasifikasi ilmu pengetahuan secara singkat. Ibnu Buthlan (dalam Asari) mengklasifikasikan ilmu yang ditekuni oleh ulama (yang wafat pada abad ke-5/11) ke dalam tiga kelompok, yaitu; 1) ilmu keagamaan; 2) ilmu klasik, seperti filsafat dan ilmu alam yang berasal dari Yunani, Persia, dan sebagainya; dan 3) ilmu sastra/adab (Asari, 1994: 68-69).

Sejauh pengetahuan kita sekarang, tidak ada dokumen tertulis yang berisi tentang rincian kurikulum suatu madrasah. Hal ini mengingat sifat madrasah tanpa ikatan organisatoris dengan madrasah lain. Oleh karena itu, setiap madrasah bebas 
menentukan kurikulumnya sendiri. Kemudian Hasan Asari menuturkan bahwa ilmu yang diajarkan di Madrasah Nidzamiyah terdiri dari ilmu agama, seperti AlQur'an, hadis, tafsir, fiqih, ushul fiqih, kalam dan sebagainya. Selain itu, ilmu sastra yang dianggap mendukung kajian ilmu agama juga diajarkan. Tetapi untuk ilmu klasik tidak diajarkan, seperti filsafat, kedokteran, astronomi, dan sejenisnya (Asari, 1994: 70).

Pendapat tersebut didukung oleh Mahmud Yunus, dia mengatakan bahwa tidak seorang pun ahli sejarah yang mengatakan bahwa diantara materi yang diajarkan di Madarasah Nidzamiyah adalah ilmu kedokteran, ilmu falak, dan ilmu pasti. Tetapi mereka hanya menyebutkan bahwa diantara meteri pelajarannya adalah nahwu, ilmu kalam, dan ilmu fiqih (Yunus, 1981: 74-75).

\section{Sistem Penggajian Guru Madrasah Nidzamiyah}

Dalam rangka melaksanakan rencana pengajaran di Madrasah Nidzamiyah, madrasah ini ditunjang dengan sarana dan prasarana yang lengkap. Hal ini bisa dilihat dari tersedianya gedung-gedung sebagai tempat belajar dan perpustakaan dengan jumlah buku lebih kurang 6.000 jilid. Buku-buku tersebut diwakafkan untuk madrasah itu (Nizar, 2011: 162). Pendanaan juga dibantu sepenuhnya baik bagi guru maupun bagi mahasiswa, mereka bebas dari biaya pendidikan dan disediakan asrama.

Sekedar untuk memperjelas pelaksanaan kurikulum di Madrasah Nidzamiyah sangat terkait dengan harta wakaf dan penghasilannya yang diperoleh dari pengelolaan harta wakaf itu, sehingga Nidzam Al-Mulk menetapkan anggaran untuk Madrasah Nidzamiyah sebesar 600.000 dinar setiap tahun (Nizar, 2011: 163). Madrasah ini juga diatur dengan sistem dan manajemen yang bagus sehingga menjadi salah satu madrasah yang termasyhur pada saat itu. Hal ini menunjukkan bahwa kesejahteraan guru terjamin karena ditunjang oleh gaji yang memadai.

\section{E. Syarat Murid dan Guru di Madrasah Nidzamiyah}

Untuk mencapai tujuan yang dirumuskan, kepala madrasah juga menetapkan peraturan, bahwa guru wajib mematuhi aturan (Saerozi, 2013: 146). Nidzam AlMulk sebagai pendiri Madarasah juga menentukan syarat yang harus dimiliki oleh seorang guru dan murid. Syarat-syarat tersebut tersimpan dalam dokumen wakaf 
Madrasah Nidzamiyah. Sebagaimana yang dikutip oleh Suwito \& Fauzan, diantara isi dokumen wakaf itu adalah sebagai berikut:

1. Nidzamiyah merupakan wakaf yang disediakan untuk kepentingan penganut Madzhab Syafi'i dalam fikih dan ushul fikih;

2. Harta benda yang diwakafkan kepada Nidzamiyah adalah untuk kepentingan madzhab Syafi'i dalam fikih dan ushul fikih;

3. Kepentingan Pejabat-pejabat utama Nidzamiyah harus bermadzhab Syafi'i dalam fikih dan ushul fikih; ini mencakup mudarris, wa'idh, dan perpustakaan;

4. Nidzamiyah harus mempunyai seorang tenaga pengajar bidang al-Qur'an.

5. Nidzamiyah harus mempunyai tenaga pengajar bidang kajian bahasa Arab; dan

6. Setiap staf menerima bagian tertentu dari penghasilan yang diperoleh dari harta wakaf Nidzmiyah (Suwito \& Fauzan, 2008: 76-77).

Berdasarkan dokumen wakaf pada poin pertama, kedua dan ketiga menunjukkan bahwa Madrasah Nidzamiyah diperuntukkan bagi kepentingan madzhab Syafi'iyah, maka semua termasuk pengurus, guru, dan murid harus bermadzhab Syafi'iyah. Selain itu Madarasah Nidzamiyah juga mempunyai guru yang ahli dalam bidang al-Qur'an dan bahasa Arab. Sehingga apabila tidak terdapat guru al-Qur'an dan bahasa Arab, maka madrasah tersebut dianggap bermasalah. Syarat-syarat seperti ini akhirnya ditiru pada salah satu madrasah di Singapura era modern ini, yaitu Madrasah Al-Iqbal Al-Islamiyah. Syarat siswa yang belajar di madrasah tersebut harus beragama Islam (Saerozi, 2013: 147).

\section{F. Aspek Sosial Politik Madrasah Nidzamiyah}

Ruang lingkup kajian politik pendidikan Islam sebanarnya tidak lepas dari aspek kebijakan (policy) dan aspek kekuasaan (power) (Mahfud, 2016: 58-59). Pendidikan adalah sebuah aktivitas sosial. Ia harus berada dan terjadi di tengahtengah masyarakat atau komunitas sosial. Masyarakat sebagai objek dan sekaligus subjek pendidikan dari waktu ke waktu terus-menerus bertambah jumlahnya. Dalam cacatan sejarah, kekuasaan Dinasti saljuk bertahan selam dua abad (Suwito \& Fauzan, 2008: 151).

Dalam kurun waktu dua abad, tentu komunitas masyakat Dinasti Saljuk bertambah banyak. Dengan bertambahnya anggota masyarakat secara otomatis 
akan meningkat pula kebutuhan dan tuntutan kehidupan yang harus dipenuhi. Pendidikan adalah bagian dari kehidupan manusia sekaligus merupakan kebutuhannya yang harus dipenuhi.

Karena jumlah anggota masyarakat semakin hari semakin bertambah, maka kebutuhan terhadap pendidikan bukan lagi menjadi persoalan individual, melainkan sudah berubah menjadi persoalan massal. Bila pendidikan sudah menjadi persoalan massal, maka perlu dicarikan lembaga pendidikan yang mampu memenuhi tuntutan dan kebutuhan massal. Madrasah pada saat itu merupakan lembaga atau institusi yang representatif untuk memenuhi tuntutan dan kebutuhan terhadap pendidikan yang bersifat massal.

Menurut Syalabi sebagaimana yang dikutip Suwito, pendidikan Madrasah Nidzamiyah itu, disamping memiliki motif kependidikan, juga memiliki motif atau kepentingan politik Dinasati Saljuk. Dinasti Buwaihi yang ditaklukkan oleh Dinasti Saljuk merupakan penganut aliran keagamaan syi'i. Dinasti saljuk sendiri menganut paham sunni. Sedangkan kedua aliran tersebut memiliki doktrin atau ideologi politik yang berbeda. Setelah kekuasaan Dinasti Buwai runtuh, mereka mencoba menanamkan pengeraruh paham keagamaannya kepada masyarakat Dinasti Saljuk melalui sebuah pendidikan. Maka dari itu, salah satu jalan yang ditempuh adalah mendirikan institusi atau lembaga pendidikan berupa madarasah yang berpusat di Baghdad dan kemudian berkembang di seluruh wilayah kekuasaan Dinasti Saljuk (Suwito \& Fauzan, 2008: 151).

\section{KESIMPULAN}

Demikian makalah ini membuka kembali sejarah singkat tentang sistem institusi Madrasah Nidzamiyah. Berdasarkan uraian di atas, maka dapat diambil kesimpulan, bahwa:

Pertama, madrasah pada awal mula didirikannya merupakan sebuah lembaga pendidikan Islam tertinggi. Meskipun demikian madrasah tidak dapat disamakan dengan universitas, karena madrasah memiliki karasteristik yang berbeda dengan univeristas.

Kedua, Madrasah Nidzamiyah sebagai madrasah terbesar memiliki beberapa misi diantaranya adalah; a) Memperbaiki keadaan kelompok Syafi'iyah den 
menciptakan stabilitas negara; dan b) mengeluarkan lulusan-lulusan untuk membantu sistem administrasi negara.

Ketiga, kurikulum yang digunakan Madrasah Nidzamiyah bermuatan tentang ilmu keagamaan dan ilmu sastra. Ilmu klsik tidak dimasukkan diajarkan, seperti filsafat, kedokteran, dan sebagainya.

Empat, gaji guru di Madrasah Nidzamiyah ditanggung oleh pemerintah. AlGhazali mengajarkan bahwa guru tidak boleh mengharapkan gaji. Karena beliau dekat dengan Nizam Al-Mulk. Oleh karena itu bisa diasumsikan bahwa Al-Ghazali kaya saat itu, sehingga dia tidak membutuhkan gaji.

Lima, guru-guru yang mengajar di Madrasah Nidzamiyah merupakan para ulama besar pada masanya. Para guru mempunyai banyak ide/gagasan, salah satunya adalah Imam Al-Ghazali yang memncetuskan ide tentang syarat yang harus dipenuhi oleh guru dan murid di Madrasah Nidzamiyah.

Enam, selama dua abad berkuasa, Dinasti Saljuk memiliki wilayah kekuasan yang sangat luas serta masyarakat yang berjumlah besar dengan latar belakang agama dan suku yang berbeda-beda. Maka untuk mencegah berkembangnya paham syi'i sekaligus menguatkan paham sunni, maka didirikan madrasah sebagai propaganda tandingan sekaligus untuk memenuhi kebutuhan masyarakat akan pendidikan.

\section{DAFTAR PUSTAKA}

Al-Furqon, Deprison, \& H. (2020). Perkembangan Madrasah Nizamiyah (Analisis Terhadap Lembaga dan Kurikulum Pendidikan Islam). Jurnal Tabuah, 24(2). Amin, S. M. (2010). Sejarah Peradaban Islam (2nd ed.). Amzah. Asari, H. (1994). Menyingkap Zaman Keemasan Islam. Mizan.

Daulay, H. P. (2009). Dinamika Pendidikan Islam di Asia Tenggara. Rineka Cipta. Mahfud, C. (2016). Politik Pendidikan Islam; Analisis Kebijakan Pendidikan Islam di Indonesia Pasca Orde baru. Pustaka Pelajar.

Moleong, L. J. (2016). Metode Penelitian Kualitatif (35th ed.). Remaja Rosdakarya.

Nizar, S. (2011). Sejarah Pendidikan Islam (4th ed.). Kencana.

Rohman, F. (2017). Pendidikan Islam; Menguak Sejarah Perkembangan Madrasah Hingga Era Nizamiyah. Jurnal Nizhamiyah, 7(2).

Saerozi, M. (2013). Pembaharuan Pendidikan Islam; Studi Historis Indonesia dan Malaysia 1990-1942. Tiara Wacana. 
42 | Sukijan Athoillah

Suwito \& Fauzan. (2008). Sejarah Sosial Pendidikan Islam (2nd ed.). Kencana.

Yunus, M. (1981). Sejarah Pendidikan Islam (3rd ed.). PT. Hidakarya Agung. 